Article

\title{
From Reality without Mysteries to the Mystery of the World: Marilena Chaui's Reading of Spinoza's Tractatus Theologico-Politicus
}

\author{
Viviane Magno
}

check for updates

Citation: Magno, V. From Reality without Mysteries to the Mystery of the World: Marilena Chaui's Reading of Spinoza's Tractatus

Theologico-Politicus. Philosophies 2021, 6, 45. https://doi.org/10.3390/ philosophies6020045

Academic Editors: Henri Krop and Pooyan Tamimi Arab

Received: 1 February 2021

Accepted: 21 May 2021

Published: 28 May 2021

Publisher's Note: MDPI stays neutral with regard to jurisdictional claims in published maps and institutional affiliations.

Copyright: (c) 2021 by the author. Licensee MDPI, Basel, Switzerland. This article is an open access article distributed under the terms and conditions of the Creative Commons Attribution (CC BY) license (https:// creativecommons.org/licenses/by/ $4.0 /)$.

1 To read more on the biography and thought of Chaui, see [2,3].

2 Montag, W. Preface [4], p. xii. Marilena Chaui

\section{Introduction}

Department of Law, Pontifical Catholic University in Rio de Janeiro, Rio de Janeiro 22541-041, Brazil; vivianemagno@puc-rio.br

\begin{abstract}
This article offers an overview of Marilena Chaui's reading of the Tractatus TheologicoPoliticus (TTP). Chaui has published numerous books and essays on Baruch Spinoza. Her twovolume study The Nerve of Reality is the culmination of a decades-long engagement with the Dutch philosopher, and her research has been a valuable resource for generations of Latin American scholars. From this extensive output, we focus on Chaui's main texts on the theological-political, concentrating on her analysis of the concept of superstition and the philosophical language of the TTP, which Chaui calls a "counter-discourse". Spinoza's enduring relevance for the interpretation of contemporary phenomena is clarified by Chaui's analysis of the TTP, which establishes a fundamentally political understanding of superstition.
\end{abstract}

Keywords: Baruch de Spinoza; theological-political treatise; political philosophy; superstition;

This article seeks to introduce readers to the work of Brazilian philosopher Marilena Chaui, with particular focus on her valuable contributions to the study of the Tractatus Theologico-Politicus (TPP). This is no small task, since Chaui's work, devoted to different aspects of the work of Baruch Spinoza, spans more than five decades. According to Santiago, Chaui's reading "constitutes one of the richest, most substantive readings ever performed of the Dutch philosopher ( . . ), endeavoring as it does to rigorously analyse Spinozian philosophy as a whole, while renewing numerous aspects of the specialized literature and offering original perspectives" ([1], p.2). In order to avoid a superficial overview of Chaui's Spinozism, we will concentrate on two main issues in Chaui's reading of the TTP, which, together, formed a guiding thread in her decades-long reflection and writings, namely superstition and philosophical language in Spinoza's TTP.

For different reasons, Chaui can be seen as participating both directly and indirectly in the powerful, renewed interest in Spinoza which took place in France in late 1960s ${ }^{1}$ [2,3]. There, some of the standout works of the period include Martial Guéroult's Spinoza: Dieu, Gilles Deleuze's Spinoza et le problème de l'expression, Alexandre Matheron's Individu et communauté chez Spinoza, and Louis Althusser and his group engaged in rereading Marx based on a decisive "detour" through Spinoza ${ }^{2}$. Already a professor and researcher in the Department of Philosophy at the University of São Paulo (USP), in October 1967, Chaui arrived at Clermont-Fernand University to continue conducting research for her dissertation, under the direction of Victor Goldschmidt. It was at that moment that Chaui 
began her work on two vital issues of Spinoza's philosophy: the critique and rejection of the negative and of contingency. ${ }^{3}$

As a PhD student, Chaui attended courses taught by Deleuze and Foucault in Paris VIII University, and became familiar with, and eventually a close friend of, Claude Lefort. Additionally, "through a tremendous stroke of luck, she was on hand to witness the Parisian May 68, which, in her own words, left her with a lasting impression of the 'experience of revolutionary possibility'. Chaui's political-intellectual adventure, however, would come to a premature end when she decided to cut her grant short and return to Brazil" ([1], p. 3.) in December, 1969. In 1970, Chaui completed her doctoral dissertation, entitled Introduction to a Reading of Spinoza [Introdução à leitura de Espinosa], and defended it following year at the USP.

Chaui's return to her native Brazil was a sobering experience of contrasting national realities. The South American country was undergoing one of its darkest moments in recent history: by 1968, the military-civilian dictatorship entered a new, more repressive phase in which basic individual rights and liberties were undermined. Policies of control and terror found their way into the universities too, and it was for that reason Chaui decided to cut her research short and return to Brazil, forming part of resistance efforts against state-intervention into the USP's Department of Philosophy.

In this political context, Chaui changed her dissertation topic and gathered together her studies of the TTP-comprising the same notes that this article will examine. She said about this period:

Given the terrible circumstances the left was facing, I felt I had the political and moral obligation to write something that made sense to people living in Brazil. I continued working on my doctoral program, but I left behind the topic of negation and contingency (or better still, embraced the concept of self-cause and absolute necessity) and began to study Spinoza's political texts, focusing on superstition and violence in a work that at that time no one was focusing on-the Tractatus Theologico-Politicus [ ... ] In the early 1970s, we not only had to fight for the existence of the department, we also had to cope with state-led terror and the dwindling hope that underground revolutionary groups could, at least, physically survive, since, as far as their political viability was concerned, their days were numbered. When we left home for the university, we never knew if we would come back that night. We did not know if our students or colleagues would be there the following day. The DOPS (Department of Political and Social Order) was in the classrooms and the teachers' lounge was wired with listening devices. A colleague would sometimes disappear, and nobody knew if they had gone into exile, if they were being tortured in prison or if they were dead. It was a period of pure fear. ([5], pp. 305-306))

In a later statement, Chaui claimed that her analysis of the TTP was written "under the sign of the dictatorship", where philosophy is practiced as a "critique of the instituted". It was, Chaui insisted, thanks to Spinoza that she managed to comprehend Brazil ${ }^{4}$. From that moment onward, Chaui employed a Spinozian perspective in order to understand the origin and function of authoritarianism in Brazil, as well as the question of ideology. That she could do so, and so convincingly, is a testament to Spinoza's enduring relevance regarding the interpretation of contemporary phenomena.

The aim of this article, however, is not to explore how the Brazilian dictatorship influenced her reading of the TTP, or how she "applied" Spinoza's philosophy to understand a contemporary political reality. Instead, the principal objective of this paper is to present

3 "My idea was to study the absence of the negative in Spinoza's philosophy, because I was influenced by Gérard Lebrun's interpretation of Hegel. Lebrun was my undergraduate professor and taught our first course in graduate school, explaining Hegel's negation of the negation, using the example of Spinoza as a perfect counterpoint to the Hegelian position. Thanks to Merleau-Ponty, I was also very interested in the issue of indetermination and contingency, whose counterpoint was the Spinozian absolute necessity", in ([5] p. 299).

4 Cf. the interview titled "C'est grâce aà Spinoza que j'ai pu comprendre le Brésil". Le Monde, Paris, 04/07/2003. 
Chaui's singular study of Spinoza's philosophical-political categories, which is strictly philosophical and universal. As Gayatri Spivak stated in her presentation of Chaui's collected works in English: “Chaui's specificity is Brazil, as Étienne Balibar's is France, and Partha Chatterjee's India. Readership of English and French have had no difficulty in finding what is universalizable in the texts of these latter two. We hope that they will proceed in the same way with Chaui" ${ }^{5}$ ([3], p. xi).

But what is it that makes Chaui's analyses universalizable? Chaui's choice to focus on Spinoza's understanding of superstition offers one possible clue. Better still, it is the method she chose to address this topic that holds part of the answer. Chaui distanced herself from systematic or structural readings, as were common under the historiographic paradigm of Guéroult in the 1960s ([1], p. 6); by contrast, under the influence of MerleauPonty, Chaui sought to find "a constellation-an invisible grouping of stars, an issue that by being absent-present plays an organizing role [ ... ] The constellation is a mesh. We shall not seek out the Spinozian system, but rather, a certain mesh. In doing so, will we lose sight of the systematizing intention behind the more geometrico? Perhaps. But on a different level, we will recover the polemical intention in Spinoza that, if philosophy finds itself lacking, reduces that philosophy itself to a skeletal structure" ([6], pp. 129-130). As Santiago underscores, by choosing to search out Spinozism at the site where it is "absentpresent" - incidentally, an area largely denigrated by Spinoza's interpreters-one may find the driving force or motivation behind his philosophical system. ${ }^{6}$ According to Chaui, that site centers on "the topic of superstition-based on which the Spinozian discourse calls for further research and itself becomes available for acquisition" ([6], p. 130). Santiago adds:

Why does superstition deserve such centrality, and how does it enable this nearmiracle by which a classic allows us to speak of ourselves and think through our own problems? In Spinozism, the entire problematic of inadequacy is connected to the issue of superstition, and, by extension, imagination, finalism, and falsity; furthermore, the philosopher's innovative approach, rooting the phenomenon of superstition in our very nature, banishes the facile images of the philosophical tradition: brute ignorance, credulity, and all the residual thoughts that science is meant to overcome. By tracing all of these intricacies, Chaui's analysis establishes a fundamentally political understanding of superstition. Superstition is a form of power exercised through fear, of violence as a resource in the political field. It is, in sum, authoritarianism. "The theory of superstition is the theory of violence", since it possesses an "authoritarian character", and it is therefore "necessary to extirpate superstition and the authoritarianism it engenders". Several passages of [Chaui's] dissertation reinforce this association, making the case that, by studying superstition, what is at stake is to understand how political authority establishes the social field from which it emerges as the enemy, making use of political violence to such an extent that politics itself becomes impossible. ([1], p. 7)

In Imagination and Power: A study of Spinoza's Political Philosophy [7], Diogo Pires Aurélio stated that the components of Spinoza's political theory are not to be found in his explicitly political texts - where the parallel with Hobbes is on display-but more in the "depths of his ontology". Similarly, Chaui established, with her own method of detection, that political implications can be drawn from the most elemental bases of the Dutch philosopher's thought. It is our intention to show how Chaui uncovered Spinoza's practical politics by focusing on superstition. But this is not all. More specifically, we shall address how the issue of superstition is explored and made evident through the logic and method proper to the philosophical language of the TTP, which Chaui calls a "counter-discourse". Chaui reads in the Theologico-Politicus a philosophy that is practiced

5 In the mentioned book [3], two articles are connected to the thematic of this special issue: "Power and Freedom: Politics in Spinoza" and "Religious Fundamentalism: The Return of the Political Theology". We decided not to bring both articles to this text since they are already translated to English.

6 "The key is the central motive that gives meaning, or origin, "not as a past 'cause', but as an uneasiness that guides the work to make itself present" ([1], p. 6). 
as a "critique of the instituted". That critique, in her view, is addressed to the "theological imagination of the era", a critique with which "Spinoza destroys the divine foundations of religion and the state" ([8], p. 95).

In this article, we will examine first how Chaui explores Spinoza's participation in the religious debates of his time, showing that the theological-political crystallizes contextdependent themes. Then, offering a philosophical approach, she investigates the Spinozian notion of imagination by considering the problematic of finalism and inadequacy. In this way, she highlights the connecting links between the first part of the Ethics and the TTP, as if Spinoza, writing the TTP, had put to work the ontological critique and argument present in the first part of the Ethics.

The second section will be on Chaui's analysis of superstition as a fundamentally political concept. Chaui studies the application of the imagination and desire in Spinoza, where what is at stake is the adequate comprehension of a given people's imaginative regime and their singular ingenium. This perspective is concerned with the anthropological and symbolic realm, wherein certain beliefs, habits and customs thrive and are reproduced, wherein the anthropological and symbolic universe of the Hebrew social body constitutes the material base for the development of a specific political field and a form of State. That is, on this second point, Chaui explores the Spinozian notion of imagination by considering its productive quality, which allows us to grasp, in a more adequate way, the relations of power, authority, and obedience of a determined social body.

Finally, in the last two sections, we will consider how Chaui interpreted Spinoza's philosophy as containing a special method to comprehend political realities, and studies opaque experiences that ask to be understood and deciphered. The TTP, then, is the lens that Spinoza's philosophy offers to readers to uncover the mysteries of a given reality.

\section{Debates on Religion in the 17th Century}

In the preface to TTP and in several letters, Spinoza clearly explains the factors that led him to write the work, which can be summarized in two objectives: to demonstrate that there is no form of speculative truth in the Scriptures, but only moral and religious teachings; and to explain the contradictions in prophetical narratives being not divine mysteries, but products of precise material conditions related to cultural, historical, linguistic, psychological, and political variations, by means of a historical, critical, and philological method. Undoubtedly, the character of this method is in sharp conflict with the basic religious and cognitive habits of his time. However, as Chaui observed, it should not be missed that, when writing the TTP, Spinoza intervenes in the debates of the early modern rationalism and among Protestants of the 17th century. The first part of Chaui's great work on the Dutch philosopher-The Nerve of Reality [8] —is dedicated to this historical context. ${ }^{7}$ The analysis is justified by the way Chaui understands the role of the history of philosophy in an author's approach: to show that "a philosophy interrogates the experience of its time, it is constituted by that experience and it is also constitutive of it, so that history is not a mere context external to the work, but history emerges from the work itself, clarifying itself in it and clarifying the work too" [9]. In other words, in her view, the relationship between the oeuvre and history is internal. Such an approach captures Spinoza's subversion clearly, in comparison with his predecessors and contemporaries, and unravels problems and arguments which are stated only implicitly in his works.

The 17th century was the golden age of the Republic of the Seven United Netherlands in economic, social, cultural, and political terms. Baruch Spinoza experiences both its heyday and decline, and the TTP is written in the interim period of political upheaval leading to the decline of the Republic. It should be added that the book was published two years before the brothers Johan and Cornelis de Witt had their bodies mutilated in public by a mad horde poisoned by the provocations of the monarchists and orthodox Calvinists.

7 In the first chapters of the book [8], Chaui addresses the main philosophical themes in the 17th century, the Dutch historical context, and the misinterpretations that led Spinozism to be considered a fatalistic philosophy, and Spinoza a deist, atheist etc. The following chapters are devoted to the misinterpretation of Spinozism in Europe after the "Spinoza" entry in Pierre Bayle's Dictionnaire Historique et Critique. 
The fields of faith and thought are no less agitated. Stimulated by the Renaissance, the Reformation, the new natural philosophy and Baconian rationalism, and then, by Descartes and Hobbes, there is a dispute about different meanings of reason, inner light, and faith. These debates are also, to some extent, influenced by the clash between revealed theology and natural religion ([8], p. 155). About the Dutch Republic of this time, Chaui notes:

Religiously and theologically, it is permeated by dramatic divisions: conflicts between Marranos, disputes between fundamentalists and rationalistic deists, controversies between Talmudists and mystical Kabbalists, between conservatives and Messianic millennialists, willing to do all the sacrifices to realize the 'hope of Israel'. (...) Thus, the community's social, economic and political conflicts always arise overdetermined, that is, always appear in the form of religious and theological conflicts in which by the use of ancient terms-such as Sadducee and Pharisee-it seeks to translate the present tensions that divide spirits, wealth, and authority. This Netherlands experienced a time of naturalistic rationalism, promoted by the renewal of stoicism by Justus Lipsius, reinforced by Grotius and Bacon (introduced by Constantijn Huygens), Descartes (endorsed by Heidanus and Coccejus), and Hobbes (who Koerbagh and Velthuysen admired), but it also underwent a time of prophets, messianisms and millenarianisms. ([8], p. 44)

Spinoza entered into the intellectual exchanges between Christian groups, initially with English Quakers, ${ }^{8}$ and later with Collegiants, unorthodox Calvinists, and libertines. In the Nerve of Reality, Chaui deals with the theme, paying special attention to the effects of the enthusiasm of "spiritual radicals" among the Reformed":

Enthusiasts are in a Catholic country, nicodemitas, the Spanish alumbrados, the millenarians of Marguerite of Navarre's court; in a Reformed country, the German theosophists and alchemists, the Dutch Anabaptists and Collegiants, and, in the mid-17th century, the radicals of the English Revolution (...). At its core is the spiritus phantasticus, the idea of inner light as inspired spiritual evidence, considered crazy by the Reformed and Roman orthodoxies, because, as they repeat to satiety, finitus non est capax infiniti (the finite is not capable of the infinite).

([8], p. 218)

The theological-political crystallizes some of these tendencies. A first important reflection of the Reformation is the inauguration of a kind of ontological democratism and a new type of relationship between the individual and God. The Reformation, by declaring most rites and ceremonies adiáphora and renewing the tension between spirit and letter, provides individual freedom for the Christian. The effects of these tendencies frightened the authorities of that time: "This spiritual intimacy between God and man could not leave the image of divine transcendence intact. Spiritual radicals find here the highest expression of what they seek in religion, that is, an ethical rebirth, not through a supernatural act performed by God through Christ, but through the experience of the union of each one with Him as parcels of life or divine heart" ([8], p. 224). That is why we have to look beyond the accusations of atheism that fell on Spinoza and understand that Spinoza does not simply oppose philosophy versus religion and faith, but philosophy versus the image of a divine transcendence, or how it will appear in the Tractatus, philosophy versus superstition. More specifically, Spinoza incorporates such discussions by developing the difference between revealed religion and natural religion in Chapters $\mathrm{XIV}$ and $\mathrm{XV}$, not by coincidence, before the political chapters.

Marilena Chaui argues that the TTP is divided into three major parts. The third part is composed of the last seven chapters of the work, including Chapters XIV and XV, which,

8 According to Chaui in [8], Spinoza's exchanges with quakers can justify the TTP's epigraph, a citation of John, the favorite apostle of quakers and others radical reformists: "Per hoc cognoscimus quod in Deo manemus, et Deus manet in nobis, quod de Spiritu suo dedit nobis" ("By this we know that we remain in God and that God remains in us, because he has given us of his Spirit"—John 4:131).

9 In one of the chapters in question [8], special attention is given to the texts of Thomas Münzer, Jacob Böhme (Aurora) and the texts of the digger Gerrard Winstaley. 
Chaui argues, operates on two simultaneous levels that interpenetrate and determine each other. At a first level, Spinoza contrasts the essence of revealed religion with what he calls another form of religiosity (natural religion). Unlike the revealed, which is caused by prophecy (the revelation of the divine will) and needs external elements (laws, rites, food prohibitions, jurisprudence), the cause of natural religion is the inner feeling of the presence of divinity in us, as the "spiritual radicals" defend. For this reason, the practice of this form of faith does not give rise to rites or ceremonies, and does not require laws. It is a relationship of each ones spiritual interiority with the others, echoing Christianity's beginnings, establishing an ethic of justice and fraternity among human beings.

This distinction is followed by another important one, that is, the difference between the Hebrew and Christian religions. Unlike the former, the latter is neither inaugurated as a political regime nor is it erected in the form of a state. Christ, unlike Moses, is only a teacher, not the founder of a state. He teaches truths for the salvation of the spirit. One is a particular religion for the Hebrew people, having a singular essence, while the other's character is universal. Thus, in Chaui's reading of the TTP, Spinoza concludes that the Christian religion only embraces politics when it is deformed into a revealed Christian religion, when the theological authorities appeal to the Old Testament. Only by fraud, violence and a desire for domination, she highlights, are the two Testaments combined and political principles produced from the Bible. In other words, in the Christian world there is no written and mystical foundation for the defense of theocracy or monarchies under divine law, which is why defending them with the support of the Bible is fraud and domination.

Having demonstrated in the opening chapters of the TTP that the theocratic nature of the Hebrew State must be seen as a historically determined singularity, the cause of which is the particular nature of the Hebrew people, it follows that it could only impose itself as a universal model of politics and religion in an aberrant, violent manner. Therefore, after excluding the revealed religions as a device to conceive political reality, Spinoza suggests to the reader a form of a natural religiosity, in which it is easier to see that religion concerns the private space, the intimate personal forum of each one, which is opposed to the public space of politics where other subjects, the multitudo, are located. By completely distinguishing religiosity from the political field, a space is opened to deduce a new, general foundation for politics.

Even more subversive, Baxter clearly perceives, is the consequence of this idea as it appears in Chapter XVI of the Theological-Political Treatise, which does nothing but repeat what enthusiastic diggers do not cease to proclaim when they break the natural and divine foundation of the hierarchy (consequence of the identity between God and Nature or of immanentism): the use of natural law to affirm that democracy is the most natural of political regimes and, with this, to destroy the natural and divine system of patriarchy in the family and in government, and, therefore, to affirm the children's right of revolt against the father and the subjects against the ruler. (...) Thus, Chapter XVI comes to the definition of democracy as "the union of a group of men who collectively hold the full right to everything that is in their power". Since law (jus) and power (potentia) are the same, the first extends as far as the second; because, in democracy, the identity of law and power is the institutional cause of the political body and its conservation, Spinoza can write: "I think, with this, having clearly and sufficiently shown what are the foundations of democratic power (...) Furthermore, I wanted to specifically express that power because it is the one best suited to my purpose: to show the usefulness of freedom in a Republic" ([8], p. 230).

\section{Superstition as a Political Concept: Spinozian Counter-Discourse}

According to Marilena Chaui, the Spinozian corpus is appreciated most fully when we grasp it as rooted in its time. That is, Spinoza's body of work does speak to us or offer us lessons because it is directly relevant to our times, or, alternatively, because it somehow addresses questions that are timeless in nature. Spinoza's writing speaks to us as a form of 
thought, i.e., "as a way of confronting opaque experiences that ask to be understood and deciphered, demanding that a new thought be developed and an unprecedented utterance be spoken, since what needs to be understood and enunciated has yet to be thought or spoken. This is the instituting dimension of Spinoza's work that reaches us when we are attentive to the temporal difference that gives it identity and posterity" ([8], p. 45).

Through his concept of substance-singular, absolutely infinite, complex, and the free, efficient and immanent cause of the universe (causa sui)—, Spinoza finds the bedrock for the demonstrative and positive dimension of his discourse, a device which illuminates the confusion of an entire epoch. That is, his discourse confronts the opaque and confusing images which impede free thought and action ([8], p. 94). The TTP forms part of Spinoza's effort to discern and elucidate opacities, and it is the contemporary "theological-political edifice" ([8], p. 96) in particular that Spinoza's seeks to critique. According to Chaui, the "Spinozian counter-discourse" attacks its three main pillars: (i) the theological-religious; (ii) the theological-metaphysical presupposition; (iii) the moral theological. Spinoza is interested in more than just mechanisms of concrete power and domination within a broader repertoire of knowledge. He addresses his critique to the "theological imagination and its images" that are rooted in all imaginative activities. That is, Spinoza does not "just" criticize religion or those particular religions that establish the common ideas about God and Nature. His attack on the contemporary theological tradition is against the commonly reproduced and widely held images - the theological image of passions and a determinate image of politics and power (of its origin, legitimacy, and quality). Regarding these "pillars", Chaui writes:

The first target of the Spinozian counter-discourse is the religious-theological pillar, in which God and Nature are grasped through the prism of analogy: both would be substances, however in different senses. His second target is the theological-metaphysical presupposition of that analogy and its consequences; that is, the images of creation, finality and divine, omnipotent and unknowable will, from which is born the image of infinite transcendence, the separation of being and power, and negative theology, which precludes the finite from ever knowing the infinite, promoting the idea of ecstasy and fusion in the absolute as a regenerating act of faith and grace. The third target is the moral-theological pillar, built on the imaginary union of freedom and willpower in God, and freedom and guilt in humankind, with all its consequences: predestination, chosenness and final judgement by God, sin, repentance, salvation or damnation for human beings. ([8], p. 94)

These pillars hold an image-producing structure, which acts in concert with inadequate ideas about God, Nature, and the human condition. Worth noting, in the Spinozian vocabulary, a "structure" - in this case, a system of life endowed with values, duties, penalties, explanations of the world, in terms of its origin, functioning and ends-is denoted by the Latin word fabrica ([1], p. 10). In several sections of Spinoza's work, we see direct attacks on this type of formulation. There are two examples from the Ethics that are of special interest here: the appendix of Part I (dealt with in the next section of this article) and the preface to Part III. In the latter, Spinoza asserts that the geometric deduction of human affects will surprise those who treat them as only vices and against all reason. As Chaui points out, Spinoza "rejects theological morality's double denaturation of human being" ([8], p. 94). ${ }^{10}$ We should recall Spinoza's words in the Ethics, III, Praef.:

Most of those who have written about the Affects, and men's way of living, seem to treat, not of natural things, which follow the common laws of nature, but of things which are outside nature. Indeed they seem to conceive man in nature

10 Chaui explains: "Where does the terrible theological image of passions come from?"; "Combining the Adamic myth, the Platonic concupiscent soul and the stoic idea of passion as a counter-nature, adding to this combination the Aristotelian metaphysics of the plurality of substances and the Jewish idea of creation, in which man is a substance created immediately by God, superior and better than Nature, but endowed with corruptible free will", ([8], p. 94). 
as a dominion within a dominion [imperium in imperio]. For they believe that man disturbs, rather than follows, the order of nature, that he has absolute power over his actions, and that he is determined only by himself. And they attribute the cause of human impotence, not to the common power of nature, but to I know not what vice of human nature, which they therefore bewail, or laugh at, or disdain, or (as usually happens) curse. And he who knows how to censure more eloquently and cunningly the weakness of the human Mind is held to be Godly. ([10], p. 491)

This brief detour through the Ethics serves to bring into focus one of the most powerful legacies that modernity has inherited from the theological tradition-produced and circulated among the four "pillars" - and which forms part of the battle waged by the TTP: "the theological tradition produces the image of imperium in imperio (dominion within a dominion" ([8], p.94) ${ }^{11}$. As Chaui points out, "the choice of the word imperium is far from accidental":

Originally meaning the unconditional power to impose laws, enforce them, and apply the use of the sword, imperium in modern language means "sovereignty". The words become central in Protestant morality, seeking it out in the Reformed version of the Apocalypse of John ("And hast made us to our God a kingdom and we shall reign on the earth") and in the Cabalist interpretation of the structure of the universe, the Tree of Life in which the final sephiroth, Malkith and the Kingdom of God and first man's sin, the seditious desire to become an "empire within an empire", a sovereign against a sovereign. Now, Spinoza not only says that the theological imagination regards humans as a vice-ridden imperium, but that it also conceives Nature imperialistically. The mark of the imperium, as its origin suggests, is its unique being. The human being and Nature therefore can only be rivals, destined for mortal struggle, and ethics can only be found beyond Nature, that is, in sovereign mankind-the cause of both virtue and of the powerlessness and volatility of passion. By man's own volition he transgresses natural law, wishing to impose on Nature his own law, which, being that its source is corrupted, violated and disturbs Nature. Natural law is the divine law that is accessible to reason, the decree of the will and the divine intellect that is comprehensible to mankind. To violate and disturb it, the human will raise up against God in an irrational gesture, "vain, absurd, horrifying". In one fateful act, the theological imagination either elevates man-placing him as sovereign before another sovereign — or brings him down and demonizes him, disowning, deploring, mocking and censuring him, demanding he abandon his own nature, taken as a contravention of nature, and that he finds another nature to make him virtuous and praiseworthy, since, if passion is deformed freedom, virtue must be obedience to the decree of the true sovereign ( ... ). The serenity to "not laugh, not deplore, not censure, but rather understand" suggest that ethics remains to be written and that in order to write it, the moral pillar built to deny man-by denying his being, having been found to be falsely elevated-must itself be demolished. ([8], p. 95)

This passage demonstrates the value of reading the TTP in connection with this part of the Ethics. Spinoza confronts the "double denaturation of human beings posed by theological morality" with a philosophical manoeuvre that seeks to naturalize affects. As Chaui shows, this naturalization does not mean simply taking affects as natural in the sense of empirically demonstrable feelings: "it is because we are, by our very nature, metaphysically affective beings" ([8], p. 95). It is obvious: we are not in fact all-powerful beings in control of our affects nor possessing sovereign free will. We are our appetites and

11 It should be observed that the term imperium is difficult to translate with a single word in English, since neither sovereignty, nor State, nor dominion, nor government express the complexity of a political structure which is composed by laws and institutions, but also by a collective imagination and affects. 
desires-efficient natural causes determined by the relations between the power internal to our being and the power of external causes. Therefore, the passions are as natural as actions, that is, properties of human nature. If so, a fundamental conclusion can be drawn about the theological tradition. Chaui writes: "virtue is not found in voluntary obedience to decrees and ends imposed by divine will, but through the increased intensity and strength of our internal power, by which we become adequate causes of our own thought and action" ([8], p. 95).

In order to become the adequate cause of our own thoughts and actions, we must know ourselves; that is, we must demand of ourselves that we build knowledge. The theological pillars and their images, as discussed above, act as unbreakable barriers to create knowledge. To the same extent, the need to combat theological tradition is not just about defeating dogmatic tenets, censorship, and the creation of mystery-enshrouded worlds, in contrast to a form of thought grounded in faith. It is instead an attack on the theological tradition which obstructs the search for adequate knowledge, the true knowledge of human nature that allows us to be the causes of our own actions and thought, i.e., that we should be allowed to create the liberty to think and act. The theological tradition is therefore an active nonknowledge, a powerful structure that constantly impedes the exercise of reason.

The confusion surrounding human nature has repercussions in the political field. Chaui reminds us that while the Tractatus Politicus is not manifestly concerned with theological matters, that work opens in a manner similar to the preface of the third part of the Ethics. ${ }^{12}$ Beyond doubt, the decisive step towards achieving the complete and perfect conclusions of the TP was the "counter-discourse" of the earlier TTP, whose target was, as previously described, the "theological-political pillar". There too the notion of imperium plays an important role, showing that "Christianity, founded on divine transcendence, built the legal-political pillar of imperium as a voluntary ( . . ) and theocratic will, because it comes directly from God's grace or special favour bestowed on his representatives as the imago Dei on Earth" ([8], p. 96). Despite the fact that Christianity provided early modernity with the foundational political model of imperium, it is important to recognize that Christianity has roots in Hebrew theocracy:

Of all the countless Christian formulations-orthodox or heretical, Catholic or Protestant, medieval or modern-there is a prevailing conception of God without which politics cannot be thought. It is this same concept that interests Spinoza, much more so than the different political theories that he does not even bother to mention nor examine, with the exception of that which serves as the foundation of all others-Hebrew theocracy. Endowed with intellect and will, God is a Person, as defined by Roman Law, and a triple Person, according to the creed of Nicaea. As a person, he is the subject of law, owner of his dominium, the world (... ) The State, incarnated in the ruler, as per the mediaeval and modern theologians, is a Mystical Person. Even when bathed in clear Aristotelian light, theology seeks to attenuate the shadowy nature of theocratic power ( . . ) Even when the state is no longer defined in theocratic terms, as mystical person, it does not cease to be person. ([8], p. 97)

Chaui's position can be clarified by her interpretation of the concept of causa sui or the single absolutely infinite and complex substance, which is the free and efficient immanent cause of the universe, based on the simple formula Deus sive Natura in the fourth part of the Ethics, which constitutes the bedrock allowing Spinoza to confront and shed light on the confusing, opaque images of his time ${ }^{13}$.

12 "Philosophers conceive the affects by which we're torn as vices, which men fall into by their own fault. That's why they usually laugh at them, weep over them, censure them, or (if they want to seem particularly holy) curse them", in ([11], p. 503).

13 "De Deo is not, explicitly, a political text. However, because in it we follow the most incisive demolition of the theological imaginary, in it we find the demolition of the foundations of theological-political power and, therefore, the conditions for the determination of the political field without the bounds of theology", in ([8], p. 95). 
Chaui summarizes Spinoza's conclusions in the first part of the Ethics in a wonderful expression: a "necessary ontology" ([12], pp. 95-128) ${ }^{14}$, without contingency or mystery. Contrary to what is maintained by Judeo-Christian thought, Spinoza shows that the world is not the result of a contingent cause- - that is, from God's free will, which could have not created the world if he either felt disinclined or did so with inscrutable designs. In last instance, if the existence of the world were necessary, God's omnipotence and divine freedom, as far as the theologians and philosophers are concerned, would be effectively annihilated. The TTP embraces this "counter-discursive" thrust unique to its era, also levelling its critique against the idea of a voluntary cause that acts contingently-that is, a divine or human will whose freedom would be proven by the contingency of its actions, by the power to do or not so something. In that sense, in Spinoza's thought, God also operates as a principle of knowledge that, in its counter-discourse, opposes the principle of personhood and mastery that the theological tradition imputes to God, with images of God persona. It is that same principle that allows Spinoza to attack the image of the state persona, contrarily deducing the foundation of the state and its sovereignty from the power of the multitude and human nature.

While the first part of the Ethics offers demonstrations at the level of ontology, in the TTP those formulations are applied against the genesis "of the same conception of God without which politics cannot be thought ( ... ), Hebrew theocracy". The TTP thus goes to the heart of the superstitious system, grasping its historical causes, revealing and confronting it as system and factory of epochal images. Even more concretely, in the TTP Spinoza builds a philosophical-political critique of the inseparable bond between European monarchies and religion, and a transcendent model of power.

Theoretically, Spinoza's critique of superstition inaugurates a new relationship with language and provokes a displacement from the meaning of the sign to the idea, from the imagination to the intellect. ( ... ) Historically, the critique of superstition takes a different tack: it takes politics and religion in its sights. It attacks the Calvinist clergy's use of the Old Testament in order to transpose to Dutch mercantilism the theocratic state of the Hebrews. The theocratic regime follows the Old Covenant-between God and the chosen people, the Hebrews. The New Testament displaces the divine pact onto men and the New Covenant refutes the clergy's pretense to control temporal matters. Superstition is allowed to dominate men by preserving their fear, flattering them with rewards, castigating them with punishments. To transform Christianity into the state religion is to use the superstition of the many for the benefit of a caste: the clergy and the royalty. The royalty thus receives a religious foundation for its political authority, while the clergy enjoys a legal cover for its ideological tyranny. The pairing of political and religious authority -therein lies what the critique of superstition sets out to combat ([6], p. 132).

This specific theological conception of divine personality—given by the Christian tradition-as transcending will and intellect continues to mark the contours of stillemerging political modernity and its definition of the nature of good governance-its origin, proper forms, and legitimacy, enabling the passage through which "theology becomes political theology" ([8], p. 98). Chaui adds: "[Political theology], based on the idea of revelation and the Roman precept of the authority of antiquitas - which allows it to use the legal foundations of Roman Law and Hebrew Law-feeds superstition and is fed by it" ([8], p. 98). The question then becomes: "What is the secret link uniting superstition and political theology?" "Could there be a theology that is not also political?" ([8], p. 98).

\section{The TTP as Lens: Desire and the Genesis of Superstition}

"If men could manage all their affairs by a definite plan, or if fortune were always favorable to them, no one would be in the grip of superstition. But often, they are in such

14 In an interview, Chaui asserts the following about this expression: "Spinoza performs an unprecedented philosophical subversion because it is the rigorous and flawless elaboration of what I call the necessary ontology. It is a subversion, because Judeo-Christian theology, modern metaphysics and contemporary ontology are dimensions and stages of the construction of hegemonic western thought, that is, the ontology of the possible, entirely rejected and criticized by Spinoza", cf. [9]. 
a tight spot that they cannot decide on any plan. Then, they usually vacillate wretchedly between hope and fear, desiring immoderately the uncertain goods of fortune, and ready to believe anything. While the mind is in doubt, it is easily driven this way or that-and all the more easily when, shaken by hope and fear, it comes to a standstill. At other times, it is over-confident, boastful and presumptuous. Everyone, I think, knows this, though most people, I believe, do not know themselves. [ .. . ] That's how crazy fear makes men. The reason, then, why superstition arises, lasts, and increases, is fear" ([11], pp. 65-67).

Introducing here in the preface of the TTP the topic of superstition, Spinoza states the two main conditions which make superstition impossible: ${ }^{15}$ wherever individuals can always decide with certainty (universally), or if chance shows them the way (by way of luck). By revisiting a classic topic dealing with the relation between human beings and contingency, the philosopher transposes his hypothesis already demonstrated in the Ethics onto the plane of experience ${ }^{16}$, while at the same time offering an unprecedented response to the discussion of how humans relate to chance. Unlike the "classical responses" on offer (Stoic or Aristotelian; virtue or praxis), Spinoza does not argue that the uncertainty experienced by individuals resides in the aleatory character of events or in the distribution of the good. For that same reason, Spinoza does not offer a means-deliberation or reason, both regarded as insufficient - to deal with contingency. According to Chaui, uncertainty is one of the core points in Spinoza's argument. Uncertainty leads Spinoza to introduce a new element in the debate around contingency: the nature of the goods that are desired-that is to say, their uncertainty. By arguing that, behind uncertainty, there is an instability regarding the possession of the things one regards as good or bad, Spinoza sheds light on the fact that human beings consider those goods as things uncertain. Contingency then does not refer to whether good things will come to pass or not, i.e., their distribution by fate, but rather, to the uncertainty of the things themselves. We should recall here the definition presented in the Ethics: men and women do not desire something because it is good, but rather, consider something to be good because they desire it ${ }^{17}$. As Chaui argues, Spinoza here subtly introduces a new idea: uncertainty lies at the heart of each individual's desire for that which they consider good. We are here in the realm of the passions, although Spinoza does not take this to mean vice, but rather, desire, that which defines things as good. After a certain point, excessive desire and uncertainty regarding the desired object can create superstition, and, as Chaui observes, this can make human beings slaves of that dynamic. The game to which contingency subjects us is, in the final instance, a game of passion-much less to do with temporality - waged, by degrees of intensity, between my passions and the passions of others.

Therefore, what is uncertain is not the aleatory distribution of benefits, but rather, the good itself. The desired object is uncertain, finding itself-whatever its nature may be-subject to contingency, whereas our desire, as an extension of our conatus, strives to conserve itself. Spinoza here effectively introduces two new elements into the classic topic of chance: the movements provoked by the excesses of desire and the object that is desired. This intense passion regime gives way to powerful affects, caused by the recognition of the uncertain presence of that which is desired by whomever either desires it or already has obtained and wishes to hold on to it: fear and hope. As demonstrated in the Ethics and in

15 "The preface begins with a conditional and negative proposition, a peculiar characteristic of Spinoza whenever, in order to demonstrate the need for a concept, it passes through the hypothesis to be rejected-any negative proposition is an absence of definition and, therefore, of reality. (...) The hypothetical judgment allows the disjunctive, and one of the disjunctions is apoditic, the other, therefore, absurd. The use of this type of judgment appears whenever the exhibition starts at the level of experience, where there is a quarrel of opinions that can only cease when one of the disjunctions is demonstrated in its apodicity. It is this passage through the apoditic that determines the final categorical judgment", in ([6], p. 133).

16 The productive principle of causa sui allows us to understand the "ontology of the necessary" and the causal network that determines all existing things. Following this principle, Spinoza demonstrates in the first part of his Ethics, Proposition 33: "Things could have been produced by God in no other way, and in no other order than they have been produced". Therefore, in the scholium 1 of this same proposition, he deduces: "that there is absolutely nothing in things on account of which they can be called contingent". The contingent is "a defect of our knowledge", "because the order of the causes is hidden from us". ([10], p. 436).

17 Cf. Ethics, III, Proposition 09, Scholium, ([10], p. 500): "So desire can be defined as appetite together with consciousness of the appetite. From all this, then, it is clear that we neither strive for, nor will, neither want, nor desire anything because we judge it to be good; on the contrary, we judge something to be good because we strive for it, will it, want it, and desire it". 
the Brief Treatise, both affects, fear and hope, must be thought of concomitantly ${ }^{18}$. What characterizes the two affects is their relation with the future and its uncertainty. Fear is defined by the risk of expecting some bad thing to pass, around which there are feelings of doubt; hope, in turn, deals with the aspiration than an uncertain good should come to pass_-"whoever fears waits and whoever waits fears", in Chaui's pithy phrasing. Grasping this rationale is fundamental for shedding light on the three elements that are at the root of the genesis of superstition. In summary, the path taken to arrive at this realization consists of: (i) rejecting or recognizing the impossibility of a rational deliberation or action that could always and in every case handle chance (being that the matter at hand pertains to the passions); (ii) the immoderate desire felt by individuals for certain good things, which are independent of them; (iii) the uncertainty surrounding the act of obtaining and maintaining the enjoyment of those good things, which is expressed through the simultaneity of fear and hope ${ }^{19}$. In light of this argumentation, Spinoza is able to also conclude that superstition is not only connected to a hypothetical aleatory regime - determined by chance and beyond our powers to control or reason. Before that, it takes as its principle the immoderation of desire and the consequent fluctuation of spirits that this dynamic subjects us to ${ }^{20}$. As Chaui observes with respect to the TTP, we find ourselves here fluctuating between doubt and petulance; the fluctuation of the spirits (fluctuatio animi)—one of the main characteristics of superstition-consists in the impossibility to follow a certain path.

Spinoza grasps superstition as belonging to the realm of the passions and the imagination, not attributing it, as theologians do, to the hypothetical weakness of human beings when faced with divine purposes. The cause of superstition is not a cognitive problem, nor an indication of intellectual feebleness or mere "gullibility", but rather, the natural effect of the human condition. Contrary to that vision, the passions and fear are grasped as those affects that set us in search of portents, signs, rituals, promises, and so on. As Chaui observes, this is what drives human beings to interpret "extravagantly" the laws of nature (following Spinoza's words from the preface- "in amazing ways"), "as if the whole of nature were as crazy as they are [et quasi tota natura cum ipsis insaniret, eandem miris modis interpretantur]. Few sentences later, in the third paragrapher, Spinoza writes about the "delusions of the imagination" [imaginationis deliria] ([11], p. 66). A similar idea, we find in the appendix of the first part of the Ethics: "they seem to have shown only that nature and the Gods are as mad as men" [nihil aliud videntur ostendisse, quam naturam deosque aeque ac homines delirare] ([10], p. 441).

Chaui here reminds us of the etymological origin of the Latin word delirare: to lose the lira - to fall out of the groove, pass the limit, as in a wanderer who loses their way. This word was associated with madness, extravagance, senselessness, the foolish-all those who have lost their senses and all "contact with reality". Not by chance, Chaui draws on the Spinozian text to grasp that the effect of this loss of contact is to draw away from and cast scorn on reason. In the latter instance, Spinoza writes, "Everyone, I think, knows this,

18 Cf., Ethics, III, Definitions of the Affects 13 ([10], p. 534): “XIII. Fear is an inconstant Sadness, born of the idea of a future or past thing whose outcome we to some extent doubt. See P18S2. Exp.: From these definitions it follows that there is neither Hope without Fear, nor Fear without Hope. For he who is suspended in Hope and doubts a thing's outcome is supposed to imagine something that excludes the existence of the future thing. And so to that extent he is saddened (by P19), and consequently, while he is suspended in Hope, he fears that the thing [he imagines] will happen. Conversely, he who is in Fear, i.e., who doubts the outcome of a thing he hates, also imagines something that excludes the existence of 15 that thing. And so (by P20) he rejoices, and hence, to that extent has Hope that the thing will not take place."

19 Cf. Ethics, III, Propostion 50, Scholium ([10], pp. 521-522): “P50: Anything whatever can be the accidental cause of Hope or Fear. ( . . . ) S: Things which are accidental causes of Hope or Fear are called good or bad omens. And insofar as these same omens are causes of Hope or Fear, they are causes of Joy or Sadness (by the definitions 11/178 of hope and fear-see P18S2); consequently (by P15C), we love them or hate them, and strive (by P28) either to use them as means to the things we hope for, or to remove them as obstacles or causes of Fear. Furthermore, as follows from P25, we are so constituted by nature that we easily believe the things we hope for, but believe only with difficulty those we fear, and that we regard them more or less highly than is just. This is the source of the Superstitions by which men are everywhere troubled. For the rest, I do not think it worth the trouble to show here the vacillations of mind which stem from Hope and Fear-since it follows simply from the definition of these affects that there is no Hope with out Fear, and no Fear without Hope (as we shall explain more fully in its place). Moreover, insofar as we hope for or fear something, we love it or hate it; so whatever we have said of Love and Hate, anyone can easily apply to Hope and Fear."

20 Cf. Ethics, III, Proposition 17, Scholium ([10], p. 504): "This constitution of the Mind which arises from two contrary affects is called vacillation of mind, which is therefore related to the affect as doubt is to the imagination (see IIP44S); nor do vacillation of mind and doubt differ from one another except in degree". 
though most people, I believe, do not know themselves". The preface thus reinforces the notion that human beings are drawn to superstition because they first ignore themselves, falling prey to the easily manipulated forms of fear and hope, taking them as external references to paper over the absence of self-knowledge.

At this point, it is necessary to return to the appendix of the first part of the Ethics, in which Spinoza seeks, based on his genetic and geometric method of exposition, to grasp why, in the mist of immanence, transcendence, with all its images and prejudices, emerges. In a certain sense, some of the arguments marshalled in the Ethics can be found summarized in the preface of the TTP. It is on account of their being at one and the same time desiring and ignorant that human beings are led to prejudice, produce images of finalism (upon which all other prejudices depend) and presuppose that "all natural things act, as men do, on account of an end" ([10], p. 439). Finalism is an all-encompassing structure of reality that interprets the real along a schema of means and ends, be it natural things or God.

Finalism is neither a vice nor a weakness, but derives from the experience of human nature itself and from the relationship established between the mind and the real. The Ethics presents two clauses that allow one to grasp this experience: first, all human beings are born ignorant of the causes of things; second, all human beings have an appetite to seek out what is useful to them, being conscious as they are of their desire. That is to say, human beings project onto reality, as if the subjective modus operandi with which they act were itself an objective explanation. It then follows throughout the text that (i) by being conscious of our appetites and volitions, we believe ourselves to be free, ignoring the causes of these desires and simply finding satisfaction as if they were their final cause. For that reason, human beings attribute to God that He is governing nature in function of human use. The finalist doctrine thus completely inverts the nature of things— "this doctrine concerning the end turns nature completely upside down" ([10], p. 442). Spinoza concludes, along these same lines, that referring to "the will of God" can equal taking refuge in "the sanctuary of ignorance" ([10], p. 443). Beyond that, (ii) human beings, by judging everything to take place in relation to themselves, also judge that what is most important is what they deem to be useful, leading them to hold as superior that which affects them favorably. The consequence of this is that they are led to create notions to explain the nature of things, such as good/evil, order/disorder, good/bad, and so on, finding themselves free of appetites and fully conscious of their desires-from which are born dualist notions like sin/virtue, and others. This merely suggests that each individual judges, first, according to the disposition of their own mind, in what Spinoza calls the mode of imaginari, a partial knowledge of the causes that lead us to act-and secondly "takes the imagination for the intellect" ([10], p. 444). That is, we take the affections of our imaginations as the things themselves (creating, "entity of imagination"), which, in the last instance, says more about our imagination than it does about the world.

Where all prejudice is based in finalism - in the formula deduced from the combination of desire and ignorance-superstition is treated in the Ethics as a broader, more systematic version of that same dynamic:

So it has happened that each of them has thought up from his own temperament [ingenio] different ways of worshipping God, so that God might love them above all the rest, and direct the whole of Nature according to the needs of their blind desire and insatiable greed. Thus this prejudice was changed into superstition, and struck deep roots in their minds. This was why each of them strove with great diligence to understand and explain the final causes of all things. But while they sought to show that nature does nothing in vain (i.e., nothing which is not of use to men), they seem to have shown only that nature and the Gods are as mad as men. See, I ask you, how the matter has turned out in the end! ([10], p. 441)

Superstition is thus taken not merely as prejudice, but as that which is transformed and takes root in the mind. What does this mean? In Chaui's reading, superstition has a complex 
structure-recalling the use of the term fabrica from the previous section. ${ }^{21}$ Superstition spreads throughout the real, like an explanatory "pillar" or principle of intelligibility of the real-explaining what human beings are, why they are, how they must act, and so on; it is also the internal structure which reproduces superstitious images responsible for a determinate social and political reality with its own ingenium. Therefore, Chaui asserts that:

Superstition sheds light on what history is. The Spinozian conception of history is not evolutionary, but rather, if the word can be allowed, is structural. Each form of the state is created through the determinate relation of political institutions and socio-ideological customs. The succession of balances and imbalances has a determinate meaning within the form itself and obeys no other totalizing principle that would provide it with a law to pass from $X$ to $Y$. This is because Spinoza does not think in evolutionary terms of superstition as a residue of the past in the present, but as a structurally determined fact that can appear in any moment and in any political form. ([6], p.224)

On the use of the word "structure", Santiago offers an important insight:

One could be led to thinking that the formula "structural history" is a tribute to the intellectual fad of its time, when everything was structurally analysed. But that is not the case ( ... ). In truth, the basis for the notion of "structural history" is Merleau-Ponty, and it links up with Chaui's deft insight regarding the concept of structure and specifically the (mistaken) opposition between structure and event that embroiled parts of the Left; for her, it is a matter of undoing this false opposition by historicizing structure ("the structure is event"). ([1], p. 9)

We shall return to the "historicization of structure" in the next section. Before continuing, we must add one additional observation regarding fear as the cause of superstition. In the preface of the TTP, Spinoza links superstition and its cause-fear-in a manner that is not repeated in the appendix to part one of the Ethics (where the emphasis falls on finalism and inadequacy). However, the close proximity between superstition and $a$ fearful reality is evident in both texts. As we read in the first lines of the above-cited passage of the appendix: "Hence, they maintained that the gods direct all things for the use of men in order to bind men to them and be held by men in the highest honor. So it has happened that each of them has thought up from his own temperament different ways of worshipping God, so that God might love them above all the rest, and direct the whole of Nature according to the needs of their blind desire and insatiable greed" ([10], p. 441).

Therefore, the fundamental elements of Spinoza's theory of superstition are present in both texts: desire, the relationship with uncertainty, the irregular sadness of fear, the madness of fluctuatio, the imagination, the possession of the desired good things, their common nature (according to the inclination of a given people), even the question of governability that must take into account for human benefit. It is based on the combination of these elements, including the desire that "God might love them above all the rest...", that the TTP will explore the topic of superstition in a practical register, that is, in terms of how it reverberates in experience. Here, Chaui argues, superstition loses its apparently weak or

21 Santiago further explores this issue and develops it in the following excerpt calling superstition the "system of fear": "Superstition is the name that can be given to what emerges from the moment when all this is systematized; as a result of the elevation of these elements to a form of system that explains, structures, organizes the real, including ourselves, our desires, our life. Superstition is a system of servitude. Its secret is the transition from the occasional and fortuitous to the necessary, systemic, structural. Qualitative transformation of the elements of our condition that superstition achieves precisely by disregarding variation, by the rarity of transitions, by the suppression of the environment; in the end, it ends the story so that your empire is as perfect, as perennial as possible. Its finished form is fatalism, to be understood in the precise sense of mystification of tensions, stiffening of the world, exhaustion of the new, ontologization of freedom and happiness (only in the beyond, paradise, the post-revolution, the post-reforms), of servitude and unhappiness (everything in this world, in this modern condition), of conscience (a substantial fact), of ignorance (which either could not be diminished or, on the contrary, would be easily overcome). We would like to understand the term superstition in this broad sense, which allows us to think of the "order of common life" that Spinoza speaks of in the Nazi camps, blind obedience, hatred of the different. But also think about the means to face it. Having recognized its secret—the dampening of variation-and its greatest effect-fatalism-the first gesture of struggle can only consist, without illusions, of restoring variation, returning to the environment and tensions, in such a way that even rediscovery of natural servitude, that is, restored to its place in the coming and going of our power, is already a gain", in ([13], p. 17). 
inoffensive attributes in which, mistakenly, we could regard it as "just" a form of madness, delirium, inadequacy of thought or irregularity. The concept of the theological-political denudes the authoritarian and violent face of superstition by transposing it onto the plane of political experience. Drawn from fear and accompanied by the sad passions (anger, ambition, deceit), superstition gives way to conflict and civil war, interminable conflicts between different superstitious structures, and, most serious of all, is the cause for power to reign over the spirits. Citing a section of the preface of the TTP, Chaui reminds us that "nothing is more efficacious than the superstition that governs the multitudes" ([8], p. 212). Rulers recognize that nothing is more effective for maintaining their rule than control over the fear of the collective, and rendering uniform all fear, hope and expectations.

In the 17th century, the source that gave superstition a degree of stability was religion, or more precisely, the theological tradition. There too lies its foundational political role -along with its texts, cults of worship, rituals, ceremonies, and laws-as the site where the fluctuatio animi is stabilized. As previously mentioned in relation to the theological tradition and its images, theological power formulates not only a metaphysics but also a theory of imperium without which European monarchies could not have maintained their rule. This involves a great deal more than religious interference in political affairs. As Chaui suggests, Spinoza is instead targeting something much more serious: that imbrication involves the invasion of a particular superstitious structure, that is, the incursion of a certain structuration of social life in the political arena formatted according to a "system of fear" that both ruins that sphere while producing servitude. Theological domination is even worse because it is invisible- "the complete possession of the other", "creating desired obedience". Politics then becomes political theology: a form of power exercised through fear, the control of the spirits, confused obedience, actively impeding the search for freedom and, above all, the recourse to violence and the authoritarian exercise of power.

As Chaui recognizes, the problem is not properly speaking the violence or authority "invariably present in social life and therefore the obligatory material of political science"22. Instead, the problem, and precisely what characterizes the political expression of superstition, is what Chaui terms the "aggravation": the aggravation of violence and authority that characterize the expression of superstition when it invades and conquers the political sphere. Aggravated superstition in politics is a form of tyranny.

The theory of superstition is the theory of violence. With it, one can delineate a philosophy of history, a political science, and a date. If in the capitalist world thus constituted, violence is determined in the form of the class struggle, in the emerging capitalist world, the historical particularization of violence is accomplished by the permanence of ideology and feudal politics, that is, by the intrusion of the clergy into temporal power. With Spinoza, the critique of superstition has a starting date.

Structurally, the critique of superstition operates as a focal point, spreading through the doctrine in a constellation of three questions: the ontological question (the critique of providence and finalism brings with the demonstration of the true nature of substance and causality); the ethical question (the critique of voluntarism and servitude clears the way to freedom of the soul in the search of bliss); the political-religious question (the critique of civil tyranny and religious fanaticism lead to a typology and a realist theory of power, as well as an absolute separation between faith and knowledge, faith and power). The idea of superstition connects a dual scheme. One is ascendant: it is its definition; the other is descendent: it is its manifestations-the origin and deformations of authority and the phenomenology of intolerance. Passion and imagination define the conditions of superstition. Obedience, tyranny, and fanaticism are its figures ([6], p. 225).

Finally, in light of this perspective, the distinctions between belief, thinking, and institutions assume a new relevance. Rational theology (an oxymoron) has the function of instilling religion with a "more solid base than the fluctuation of human passions",

22 "The Political Treatise and the Theological-Political Treatise were written to define the possible field of violence, and not to deny it. Neither satire nor utopia. Politics.", in ([6], p. 190). 
a stability that religion alone cannot attain ([12], p. 10). In doing so, rational theology is present as "the imposition of the image of authority as the source of constancy and solidity". Along those same lines, Chaui, advances a foundational reading based on the TTP: theology and philosophy differ not based "on the type of truth they attain, but on the type of practice they produce":

Theology is the imaginary theory of contingency. Centred on the image of an omnipotent and transcendent will that creates and governs the world, the theological imagination offers explanations that preserve fear and hope, leaving humans in suspense before the unforeseeable plan of a higher power; ( . . ) This is why the Theological-Political Treatise categorically declares that the only truth of theology is in teaching obedience (...). Hence, what separates theology and philosophy is not a sensible distribution of competencies, each one possessing exclusive, non-negating truths, where each could be considered a different arena of knowledge. Philosophy and theology are not distinguished by the content of their truths but rather by the different demands they pose to whomever wishes to think: theology demands obedience and intellectual submission; philosophy the free exercise of thought. ([12], p. 9)

In the TTP, the terrain of dispute between theology and philosophy is thus not concerned with the kinds of knowledge or the truth they instantiate. They are cast in opposition due to the different effects of practice they produce. The political register of theology is theocracy, authority, obedience, and servitude; and the practical register of philosophyhow does it then consist in the realization of the freedom to think?

\section{The TTP as Lens: Creating a Counter-Discourse}

Above we cited one of Chaui's most celebrated phrases: "theoretically, the critique of superstition in Spinoza inaugurates a new relation with language and stimulates a displacement from the sign to the idea, from the imagination to the intellect" ([6], p. 132). She stands: "From Xenophanes to Lucretius, the criticism of superstition has always been the privileged theme of Naturalism. Theoretically, Spinoza's criticism is inaugural. Its radical novelty is the relationship it establishes between the reader and the text $(\ldots)^{\prime \prime}$ ([6], p. 131). In the book From reality without mysteries to the mystery of the world [14], Chaui analyses in greater detail this relation, concluding that Spinoza develops a discourse in the TTP that is both capable of disassembling the imaginary discourse and its images, and laying the groundwork for a counter-discourse. According to Chaui, Spinoza neither sets out to inaugurate a "more" rational—or truly rational—truth, nor even less a truth different from theological truth. However, Spinoza practices a philosophy which creates a new language containing his method, committed to developing adequate knowledge. To that end, Spinoza, employs a critical method, providing a determinate discourse-based on a given socio-political reality - and its modes of structuring and grounding itself in the real, even where that means impeding free thinking and action. Chaui observes: "The true and free discourse can only be born and develop according to an internal necessity that unveils the engendering of all things and human practices, and which is offered as reflection and critique. Free discourse is that which is capable of proffering its own inside and that which makes possible and impossible-it is both discourse and counter-discourse" ([14], p. 97). The first step along that path is the employment of a real and genetic method of definition. ${ }^{23}$

Accordingly, Chaui structures the Treatise in three large parts. The first is composed of a preface and six first chapters in which Spinoza employs a deductive approach, offering a real definition of religion. In Chapter VII Spinoza offers his interpretive method for Scripture. That method is inaugurated in the second part of the TTP, and follows an exegetical path of biblical interpretation based on the principle ex sola Scriptura. Finally, the third part returns

23 "The reader of the TTP will see this operation take place on two levels: philology and etymology set out in search of the place of spontaneous emergence of words, (...). However, a third, underground level runs through the investigation: one that interprets the emergence of rhetoric and metaphor as instruments of political manipulation of the text", in ([14], p. 79). 
to the deductive approach, offering a real definition of imperium and its natural foundation in politics. Many scholars diverge over the issue why Spinoza describes his method only in Chapter VII, and not in the beginning of the work. Another striking element is the manner in which Spinoza distances himself from the Cartesian method typical of the era, implying an ideal rationalist reading of Biblical texts, as his friend Lodewijk Meijer, in Philosophy as the Interpreter of Holy Scripture ([12], p. 30). As stated before, Spinoza is not interested in the truth of these texts, but rather, in their unique meaning. This is the guiding principle behind Spinoza's use of the Protestant principle of ex sola Scriptura, removing any idea or concept external to the sacred text.

Chaui notes that it is quite understandable that Spinoza would only present his method after the first chapters. After all, according to Spinoza, to proceed to the knowledge of something, one has to start from the real definition of the thing that is to be known. Just as in the Ethics, where Spinoza proposes a real definition of the circle based on the cause that produced this object to be known, in the TTP, he investigates the productive causes of religion in order to subsequently develop, in an immanent fashion, a method that satisfies his object. It follows that it is necessary to understand the genesis of religion before trying to interpret the texts in which it is enshrined:

Historian, ethnologist, philologist and political writer, Spinoza approaches the document and deciphers it through the figure of its authors, recipients, and censors, in such a way that reading leaves the singularity of the discourse intact and makes with that a plot of the text in such a way that the existence of a singular people comes into focus. The Hebrew people are the document, but they have a meaning that can be deciphered by their own way of constituting themselves as a document. Thus, not only will the text tell us about who were the people who produced it, but also, by making these people known to us, it will enable us to understand the peculiar nature of the text that it produced. ([12], p. 17)

Chapters I through VI address a particular revealed religion. Therefore, it is necessary to define that religion and provide a method of interpreting the texts in which that revealed religion manifests itself:

Spinoza therefore constructs the real definition of the object "revealed religion" and presents its general properties in light of a particular revealed religion, the Hebrew religion. What is a revealed religion? A revealed religion is made up of divine messages or prophecies, given by determinate agents, the prophets. Therefore, it is necessary to know what a prophecy and a prophet are and if they indeed exist in every revealed religion-Chapters I, II and III deal with this very topic. (... ) Rather than establishing the uniformity of beliefs and conduct (...) the diverse array of disputes, controversies and violence have always depended on the different ways in which they were read. It is therefore a question of what would have caused this variation and its terrible consequences, and, in the light of the answers found, to propose a new way of reading that respects the revelation, without infringing on religious precepts (of worshiping God and loving others) and ensuring the unity between peace and piety-this is the subject of Chapter VII, concerned with methodological innovation. The chapter on the method presupposes, therefore, the real definition of its object and offers an approach to revealed religion that proffered revelations in writing. Thus, the first six chapters (offering a rational definition of the object) are not incompatible with the seventh chapter (interpreting ex sola Scriptura), because their objects are not the same and the interpretation that will be carried out does not intend to rationalize the contents and the form of religious writings, but rather find its meaning, coming to know the language in which they were written and the history of the people who wrote and read them. ([12], p. 32)

This admittedly long analysis is fundamental for grasping Chaui's argument about the structure of the TTP: to understand how the TTP establishes a new relationship with 
language and affects a shift from the sign towards the idea. Unlike Meijer, Spinoza does not intend to rationalize the contents and forms of religious writings, but rather, to find their meaning. However, the question remains: how is the text capable of constructing a philosophical language capable of effecting the transition from imagination to intellect?

As mentioned, according to Chaui, the three parts of the TTP form a logical and interlocking course of demonstration. In the initial part, Chapters I to VI, in keeping with the principle of developing a real definition of the object, Spinoza explores the symbolic field, grasping a given people according to their idiosyncratic madness while scrutinizing their imaginative regime in order to understand the structuring history of this superstitious system. The appropriate method then flows logically from that part, in Chapter VII. There, the exegetical method is applied to the Scriptures, until reaching Chapter XV, whose main consequence-made possible only as the groundwork had already been laid-is to propose a distinction between faith, natural light, and reason, and between theology and philosophy.

These two parts of the argument are premises for demonstrating that theology and philosophy follow different paths. However, this is not done by invalidating or denying the underlying superstition of the theological system. On the contrary, Spinoza acknowledges their points of contact and difference, trying to conceive the singular nature. Prophecy, Spinoza concludes, is also knowledge, but it is imaginative knowledge, which, in Chaui's words, "goes beyond what the intellect allows one to know and therefore falls short and is not true knowledge. This does not invalidate the prophetic imagination, as Spinoza makes clear that the prophet is not a theologian" ([12], p. 84). In Chapter XV, Spinoza states that, because revelation constitutes a productive system of images, i.e., of indicative and imperative signs, we cannot obtain true knowledge of God's essence and potentia through it. He thus outlines the proper place of theology, which, according to Chaui's reading, consists of:

a system of images with a conceptual pretence whose scope is to obtain, on the one hand, the recognition of the theologian's authority (and not the intrinsic truth of his interpretation) and, on the other, the submission of those who listen to him, all the greater if it is achieved by inner consent. The theologian aims at the desire to obey and to serve. In this way, the difference between philosophy and theology becomes clear. Philosophy is to know. Theology, non-knowledge, is a practice of religious origin designed to create and preserve authorities by encouraging the desire for obedience. ([12], p. 84)

Having outlined the practical consequence of theology, which is none other than the authoritarian intervention in the field of politics, Spinoza at the end of the second part of the TTP, Chapter XV, ensures that "before moving on to politics, readers have been made to understand that the Hebrew state was a theocracy and why that state cannot be seen as the perennial rational model of all states" ([12], p. 84). If that state cannot be a model for others, then where should the foundations of a state be derived from? From Chapter XVI on, Spinoza in a third movement presents the foundations of political power, and the genesis of the State (or imperium), by making a rational reconstruction of political foundations. Thus, in the same way that Spinoza gives, from Chapter I to VI, a real definition of his object, justifying the use of his chosen exegetical method, from Chapter XVI onwards he develops the real definition of imperium, which will then require another method of demonstration. The TTP's argumentation takes us "by the hand" ([10], p. 446) to understand, following the uniqueness of each human activity (believing, thinking, and organizing), the need to apply another method to deduce the foundations of politics. If the basis of those three activities is different, their authorities must follow the same principle. That is, just as the first object ("revealed religion") led to the need for a method of interpretation all its own, the second will lead to the need for a purely rational deduction of the foundations of political power. In Chaui's words, the freedom of thought proposed in the TTP is the full visibility of political practice; the text, from within and from its foundations, "creates its reader as a philosopher"; a "speech without a master", which, on the contrary, denounces the source of authority. 
The genius of the Spinozian work is precisely in offering us the necessary separation between religion and politics, faith and reason, theology and philosophy through the discursive structure itself: it is in the form, not the construction of the text, that Spinoza lets us see the content or the theses proposed by the Tractatus. (...) The reader-philosopher also notes that, despite the sinuous and intricate form of the arguments, each of the chapters and the book as a whole always follows three main lines: the first traces the specificity of Scripture in the face of theological manipulations and thus indicates the way in which theological power is exercised; the second traces the difference between theology and philosophy and, therefore, the difference between authoritarian nonknowledge and free knowledge; the third, finally, traces the uniqueness of the Hebrew people and their document and then points out the difference between ideology and historical knowledge. Whatever the topic addressed, these lines will always be present, determine each other and allow not only to demonstrate the impossibility of theology to attain true knowledge, but above all to determine the origin of theology itself from the historical knowledge of the document from which it is an effect; an origin that it needs to hide in order to guarantee the exercise of a power that the text guarantees by sacralizing it and concealing it as a document ([12], p. 33).

As the TTP shows, the mystery is neither in the Scriptures-in its content or in the form of its text-nor in the impulse to consider it as mysterious; it is in the interpreters, "in the skill to turn words on and off, the theological adventures of theology created a book unable to survive without authorized interpreters. Reading has become the power of the few and the obedience of many" ([14], p. 96). For this reason, Chaui affirms that the TTP is not only a book where power and authority are considered, but a place "where speaking is already an act of freedom, because the form of that speech/writing has taken a position with respect to power and freedom in their links with knowledge".

Due to its content and form, the Spinozian discourse is internally articulated. His philosophy is born out of the radical criticism of a transcendent authority, installed in the movement of the causa sui and the conatus (...). At the same time, it reveals the intellectual and affective operations that support the movement of the true and the imaginary machinations, which activate devices for the concealed exercise of authority. (...) His discourse is also liberation. And the opening of the theological-political meets up with the final lines of Ethics: "If the way I have shown to lead to these things now seems very hard, still, it can be found. And of course, what is found so rarely must be hard. For if salvation were at hand, and could be found without great effort, how could nearly everyone neglect it? But all things excellent are as difficult as they are rare"([14], pp. 97-98) ${ }^{24}$.

We can now return to the question that was left open in the previous section: "and the practical register of philosophy-how does it then consist in the realization of the freedom to think?" The answer can be found in the Theological-Political Treatise itself, a work realized as a form of a "critique of the instituted" in past and present, where speaking is already an act of freedom and where discourse causes liberation, creating the reader as philosopher, to use Chaui's terms.

This is the case even after 350 years, according to Chaui. On the first page of The Nerve of Reality, she wonders about the possibility of recovering a classic in the present. Echoing Spinoza's Ovid-inspired words in the TTP, she wonders: how to reach the meaning of texts written in a language where words, idioms and motifs have been lost, in which the meaning of countless words has become incomprehensible and for which "we do not have

24 On this point, Chaui adds: "If thinking is acting, putting yourself in the immanent movement of true ideas, thinking is already a practice of freedom. If man appears in all Spinoza's works, originally submerged in the waves of the imagination, ignorant and slave, it becomes essential to find the place where Spinoza's speech can be born, marking his own possibility as a speech of freedom. In the excavation of immediate experience, in the conflicting practices of each man in his relationship with others and with things, in breaking the obstacles that the hammer of intellect reduces to dust, the space opens up where freedom and happiness will excavate their paths. The place where Spinoza's discourse will be born is demarcated by the internal criticism of what would make it impossible: the critique of the limit form of authority, that is, of theological, metaphysical and moral tyranny and of its legitimate political manifestations", in ([14], p. 88). 
dictionary, grammar or rhetoric?" With what strength will we overcome "the voraciousness of time that abolishes everything from the memory of men"?

Although we have presented a very specific aspect of Chaui's reading of the TTP, i.e., her interpretation of the political meaning of superstition, her method reveals a very original dimension, insofar as it combines a philosophical with a political reading of Spinoza's work, articulating several dimensions of his philosophy through textual analysis. Ontology, theory of knowledge, method, language, history, and philology, the same layers present in Spinoza's thought, are mobilized for the reconstruction of the discourse of the Dutch philosopher. Chaui's reading allows us to understand Spinoza's discourse in all its uniqueness, in its relationship with time, with history, and with the philosopher's own experience. By doing so, she unveils what is properly subversive in his philosophy, i.e., the way in which he simultaneously criticizes the dominant thought of his time while introducing a difference in the very way of enunciating that critique. Chaui reconstructs his discourse as a "counter-discourse" that dismantles dominant thought, asserting itself as an instituting discourse of an unprecedented thought. In other words, the construction of a discourse that is not only "against", but a discourse that, by criticizing that which exists, situates itself as a new way of enunciating the problems of an era. This is what Chaui's reading teaches us: a way of deciphering the opaque experiences of our present, as the author did and continues to do in relation to the Brazilian reality, or, as Jorge Luis Borges poetically expressed it: "Free of metaphor and myth, he grinds a stubborn crystal: the infinite map of the One who is all His stars" ([15], p. 285).

Funding: This research received no external funding.

Conflicts of Interest: The author declares no conflict of interest.

\section{References}

1. Santiago, H. Spinoza contra a Ditadura Militar Brasileira. In Santa Barbara Portuguese Studies; University of California Santa Barbara: Santa Barbara, CA, USA, 2018; Volume 2.

2. Revista de Cultura Papel Máquina. Editorial Palinodia: Santiago, Chile; 2017, Volume 11. Available online: https://palinodia.cl/ wp-content/uploads/2019/05/Papel-Maquina-11.pdf (accessed on 29 November 2020).

3. Chaui, M. Between Conformity and Resistance: Essays on Politics, Culture, and the State; Conde, M., Translator; Palgrave Macmillan: New York, NY, USA, 2011.

4. Balibar, E. Spinoza and Politics; Snowdon, P., Translator; Verso: New York, NY, USA, 2008.

5. Chaui, M. Entrevista. In Conversas com Filósofos Brasileiros; Nobre, M., Rego, J.M., Eds.; Editora 34: Rio de Janeiro, Brasil, 2000; pp. 305-306.

6. Chaui, M. Introdução à leitura de Spinoza. Ph.D. Thesis, Universidade de São Paulo, de São Paulo, Brasil, 1971.

7. Aurélio, D. Imaginação e Poder: Estudo Sobre a Filosofia Política de Espinosa; Edições Colibri: Lisboa, Portugal, 2000.

8. Chaui, M. A Nervura do Real: Imanência e Liberdade em Espinosa, 3rd ed.; Companhia das Letras: São Paulo, Brasil, 2006.

9. Folha de São Paulo Newspaper: São Paulo, Brasil; 1999. Available online: https://www1.folha.uol.com.br/fsp/resenha/rs13039 901.htm (accessed on 20 December 2020).

10. Spinoza, B. The Collected Works of Spinoza I; Curley, E., Ed.; Curley, E., Translator; Princeton University Press: Princeton, NJ, USA, 1985.

11. Spinoza, B. The Collected Works of Spinoza II; Curley, E., Ed.; Curley, E., Translator; Princeton University Press: Princeton, NJ, USA, 2016.

12. Chaui, M. Politica em Espinosa; Companhia das Letras: São Paulo, Brasil, 2003.

13. Santiago, H. Entre servidão e Liberdade. In Cadernos Espinosanos; Universidade de São Paulo: São Paulo, Brasil, 2012; Volume 26, pp. 11-23.

14. Chaui, M. Da realidade sem Mistérios ao Mistério do Mundo, 2nd ed.; Editora Brasiliense: São Paulo, Brasil, 1981.

15. Borges, J. Borges, A Reader: A Selection from the Writings of Jorge Luis Borges; Monegal, E.R., Reid, A., Eds.; Howard, R.; Rennert, C., Translators; Dutton: New York, NY, USA, 1981. 